\title{
The meaning of freedom during the Cold War in the light of Andrzej Bobkowski's Guatemalan prose
}

\section{Introduction}

This article explores how the Polish writer Andrzej Bobkowski understood the meaning of freedom in the post-WWII world and shows that it was this understanding that prompted him to leave Europe, which he believed had lost its values. Bobkowski's life mirrors the vicissitudes of 20th century history: he belonged to the first generation of Poles who had tasted the freedom and independence regained after 123 years of partitions. The outbreak of the World War II, however, brought his compatriots' optimism and activism to a sudden halt. In the spring of 1939, during the time of the Polish Second Republic, Bobkowski travelled to France. Greatly disappointed with the post-war political order in Europe after World War II, he left the old continent. It was clear in his mind that he could not return from France to the People's Republic of Poland for political reasons. He selected Guatemala as his destination with no inkling that he would have to encounter communism there too.

Freedom, independence and dignity are values of universal importance that become all the more appealing the less they are respected, and they were certainly crucial to Bobkowski. It is a love of freedom that appears to be at the core of Polish identity. For centuries Poles proudly displayed their devotion to freedom, which they understood in a national as well as an individual sense. As noted by Pawel Dybel, being a Pole is characterized by "a fierce love of democracy, an enduring yearning for freedom, and an age-long attachment to tolerance" (Dybel, 2021). This strong yearning for independence and freedom of choice influenced Bobkowski as a Polish writer from the very beginning of his writing career, but at the same time the turbulent history of the 20th century meant that the word "freedom" would come to be redefined. Bobkowski not only inherited the Polish devotion to freedom, but he also found his own understanding of "freedom" in the post-war world by working as a model-maker captivated by the universal dream of flying. 


\section{Andrzej Bobkowski-Querido Bob}

In choosing to present a portrait of Bobkowski I am clearly aware that my choice cannot be justified with the simple and straightforward argument that he is "a famous and outstanding Polish writer". Only in recent years has he begun to find a place in the Polish literary canon. Why was his figure so shrouded in silence? A number of reasons exist for this "pall of silence". Firstly, Bobkowski’s contrarian individualism did not strike a chord with Polish readers. His Sketches with a Feather did not stir Polish people's awareness, the trauma of WWII in Polish territory could not have been either equated with, or even compared to life in France under occupation, and the reader on the banks of the Vistula had completely different expectations of literature at that time: the Polish reader expected literature to be a witness of the crimes committed. Secondly, Bobkowski was not allowed to publish his works in PRL (People's Republic of Poland) due to the ban imposed by the Main Office for Press Control and censorship. Thirdly, Bobkowski was unfairly suspected first of collaborating with the German secret service, and then, unusually, with the French secret service. All these reasons contributed to the writer's isolation, even in émigré circles, a point which he himself acknowledged in a letter to Jerzy Giedroyć (Giedroyć, 1997, 633). The fourth, and the most significant reason in my opinion is that no one described quite the way Bobkowski did. According to Roman Zimand (1984, 23-24) Sketches with a Feather raise the fundamental issue of freedom and individuality. Joseph Czapski (Czapski, 1961, nr 167) emphasized that Bobkowski was a rebel by nature, undermining authority and laying bare questionable Polish national traits, and such unavoidably extreme individualism has a tendency to stir up trouble.

I argue that Bobkowski creatively implemented a paradigm of Joseph Conrad's values which included fidelity, loyalty and duty. Conrad served as a model and point of reference for him, a point he himself elaborated on in the essay "Biography of the Great Cosmo Pole" (Bobkowski, 1998). Bobkowski wrote the essay after he had been diagnosed with stomach cancer and became aware of the short time that remained for him. This particular essay seems to have been not only a homage to Conrad but was also an intimate testament and autobiographical testimony. The testimony of an émigré, who had lost everything, even the hope of a return to the mother country. Nevertheless, he remained true to himself and cherished his composite biography: from Conrad, it was the biography of a child of patriotic parents orphaned young, a mariner and a writer; from Bobkowski, it was the biography of a model maker and a writer.

Bobkowski endeavoured to find "a point of balance" in the post-war world, which was so different from the one he encountered when he was born in Wiener Neustadt in Austria in 1913, the son of Henryk Bobkowski, a professor at the Theresian Academy (Kaliszewski 2003, online) and Stanisława Malinowska, a talented and sensitive 
woman from Vilnius. He was born as a Pole, not as an émigré but a citizen of the Austro-Hungarian Empire that for over 120 years ruled the southern part of Poland after it had partitioned by Russia, Prussia, and Austria in the $19^{\text {th }}$ century (Davies, 2005, 218, 225, 284, 321). Bobkowski spent his childhood in many places such as Lida, Vilnius, Modlin and Krakow where he graduated in 1933. Between 1933 and 36 he studied economics at the Warsaw School of Economics. He married Barbara Birtus in 1938 and in March 1939 moved to France with his wife, where initially he opened a laundry and then started to work in an ammunition factory in Châtillon near Paris. After France's surrender, he was evacuated with the factory to the south. He attempted to join the Polish army but did not succeed - probably due to the suspicion of espionage mentioned above. He decided to return to Paris by bike and he later gave an account of this extraordinary journey in Sketches with a Feather (1957). After the war, he worked in the liquidation office of the Atelier de Construction de Châtillon as well as the manager of the Polish Bookshop and in the Polish YMCA ${ }^{1}$. He co-edited with Andrzej Chciuk the underground periodical 'Razem Młodzi Przyjaciele' ('All Together Young Friends') which was published in Lyon between February 1945 and May 1947 (Kaliszewski 2003, online). Bobkowski became involved with the Polish 'Independence and Democracy' organization in exile. Gradually he developed his reflections on the post-war world and published articles on post-Yalta Europe and European culture.

The author of Coco de Oro considered freedom and independence to be the most important of European values, which understood to involve action, responsibility, creativity, and perseverance, however he felt that was not able to find them in Europe anymore. He discussed the condition of Western Europe in an imaginary interview with himself "Pytania dzikich ludzi"/ "Savages' questions", printed in "Culture" in 1951:

"Europe? Comfort seeking and cowardly replaced pars pro toto [the] term 'Europe' and its essence and meaning dissolved in it so completely, that even the brightest Europeans are not aware of it" (Bobkowski, 1951, 25).

For Bobkowski, comfort seeking seems to be the dominant source of destruction and needs to be understood on various levels: as a lack of readiness to confront evil forces and to defend one's values, hesitation to express clearly one's opinion and pretending to believe the lies spread by politicians. Comfort seeking stands in an ironic contrast to the medieval European idea of a knight as well as to the associations with honour and bravery that shaped the European concept of masculinity in general.

1 During Second World War the Polish YMCA was closed by the Nazis, but the Polish movement continued to work in France, England, Romania and even in Africa with the Polish Army of General Anders (https://www.ymca.int/member/ymca-in-europe/ymca-poland/). 
Deprived of energy and creative force, helplessly accepting the new order, despite the lesson of the totalitarian experience of WWII, post-war Europe came to negate itself. Bobkowski therefore emigrated with his wife to Guatemala in 1948 with the dream of a new beginning and of a new life (Kaliszewski 2003, online). I would hesitate to claim that it was a naïve or romantic decision of symbolic nature. Hanna Gosk, referring to an unpublished report, found in the Polish Institute of Arts and Sciences of America (PIASA) suggests that Bobkowski was tempted to return to People's Republic of Poland by Jarosław Iwaszkiewicz and Jerzy Borejsza whom he met in Paris on 22 May 1948 (Gosk 2011, 98-107). As has been confirmed in many other cases, Polish writers, who had escaped or been expelled from Poland during the war or had imprisoned by the invading forces, were encouraged to return to People's Republic of Poland and legitimize the new communist rulers. Many of them, including Bobkowski, refused to do so. It can be argued that to him socialism embodied everything contrary to the educated middle class paradigm of values as Andrzej Kowalczyk has shown (Kowalczyk 2011, 197-213).

Bobkowski left Europe without money, without a command of Spanish and even without a clear idea what he would do in Guatemala. Finding his feet in Guatemala took about seven years, which he summed up as travelling through a typhoon. In Guatemala he opened a model-making hobby Shop that in a few years became a wellknown institution that was the greatest testimony to his serious engagement in building a new life in his adopted country. He wrote in a letter to Andrzej Chciuk in 1957: "I adore my adopted country. I feel great here and I would come back to my Homeland only if I lost my mind. Nobody will pull the wool over my eyes, because in the present political system, even after October [Polish October '56], nothing can be built' (Terlecki, 1999, 154).

These words express vividly his disbelief in the possibility of a change in the communist regime ${ }^{2}$ in the People's Republic of Poland after the disappointment of the Polish October ${ }^{3}$. Paradoxically, to remain a Pole and a European, he had to live his values outside of the culture where had been brought up. This fact subverts the idea of colonialism as a civilising mission, which presents European civilization as a refuge from disappointment and as a quest for seeking a ground zero to rescue its integrity. The mission no longer aims to spread civilisation but to find a haven for the ideas that had once constructed it. Once power becomes all-important, the dignity of a human being comes into question. It is worth noting that colonial domination could be easily substituted with communist internationalism. Bobkowski saw such a pattern and this was the reason why he distanced himself from Guatemalan politics.

2 See: Applebaum, Anne (2012). Iron Curtain: The Crushing of Eastern Europe 1944-1956. New York USA: Doubleday.

3 See: Kemp-Welch, Tony. "Dethroning Stalin: Poland 1956 and its Legacy. Europe-Asia Studies 58 (2006): 1261-84. 
Bobkowski therefore lived a very humble ordinary life in Guatemala. Bobkowski choose his own mentors - the novelist Joseph Conrad and composer Fryderyk Chopin - who paved a new patriotic path for Polish emigrants in the 19th century. Conrad, like Chopin, knew that Poles had to leave their motherland and could not return there because Poland did not exist as a country anymore as the result of the tiple partition of Poland implemented by Russia, Germany and Austria-Hungary. The Soviet Union's strong influence and its domination over the Polish Peoples' Republic was reminiscent for Bobkowski of the time when Poland disappeared from the European map in the 19 th century.

Reflecting in a sense Conrad's biography, Bobkowski made a radical decision to leave for Guatemala. He repudiated everything - Poland in the shape given to her in Potsdam and Yalta as well as Europe itself - and opted for life in what he considered to be a primeval land. This was his liberum veto ${ }^{4}$.

This was the decision of an artist in search of new stimuli, but it was also a decision made by a man who takes responsibility for shaping his own fate. Despite his admiration for Conrad, he did not decide to develop his literary talent and write extensively either in Polish or in any other language. His literary output seems not to be very extensive, and a considerable part of it consists of essays and commentaries upon Polish affairs published in Culture - an independent Polish monthly issued in exile in Paris and edited by Jerzy Giedroyc. Contemporary Polish critics consider Bobkowski's talent to have been wasted, under-utilised or even squandered (Sambor, 1964, 176-179; Nowak, 2020).

Bobkowski, like Conrad, worked hard to become a true professional and a reliable business partner who encouraged other to dream and also inspired them. From Chopin Bobkowski learned how to be cosmopolitan, how to find fulfilment in universal values and how to break free from the Polish romantic stereotype of an unhappy artist condemned to suffer. Consequently, one thing he avoided was to expect mercy or compassion. Instead of being a victim of history, he wanted to contribute to it with his talent and hard work. Andrzej Bobkowski also proved his character in very private matters as he fought bravely against cancer for several years. He died in Guatemala on the 26th of June 1961. Senior Andres, as Bobkowski was called by the young model-makers, was buried in the grave of a respected family: Mausoleo de la familia Quevedo Ávila-Escobar Vega in the Cementerio General de la Ciudad de Guatemala,

4 The phrase liberum veto comes from Latin and refers to a parliamentary a unanimous voting rule in the Polish-Lithuanian Commonwealth. This rule allowed any member of the Parliament to hold up its proceedings and in effect bring the Commonwealth to the brink of collapse. Regardless of how liberum veto has been utilised from a historical and political perspective, this rule was based on the premise of the equality of all Polish noblemen and has remained very attractive to generations of Poles. For further reading see: Wandycz, Piotr (2001). The Price of Freedom. A History of East Central Europe from the Middle Ages to the Present. London and New York: Routledge. 
Calle Central, lado sur, cuadro 6, mausoleo 34. It is difficult to find the right term to encapsulate Bobkowski's personality, as it eludes ready-coined categorisations, but one proposed by Wolfgang Welsh could perhaps be appropriate: an open personality.

\section{Freedom, independence, uniqueness}

In Bobkowski's work freedom is manifested in many ways: political freedom, freedom from the Nazi occupation, freedom from the communist regime, freedom from the stereotype of 19th-century role of the Polish émigré, freedom to write without censorship, freedom of speech and freedom of movement. All of these aspects of freedom are nurtured in Bobkowski's writings and are a testimony to the times in which he lived when the issue of freedom was extensively debated. It is worth noting that his idea of freedom embodies two notions: "a freedom from" and "a freedom to/for". Only the achievement of both appears sufficient for a person to truly attain freedom. This was the philosophy of Erich Fromm and Hermann Keyserling, whom Bobkowski regarded as modern-day Socrateses (Bobkowski 2009b, 25) and who would in turn influence the writer's world-view.

Part of Bobkowski's manifestation of the "freedom to/for" concept was his choice to emigrate to Guatemala where there was no well-established Polish community that could have supported him nor where there were any scholarships or any structures to provide him with financial security. He declared many times that he desired to be so free that he could die unnoticed. At the same time, his emigration appeared as break for freedom from the European trauma of war, Soviet domination as well as freedom from censorship. He explained his fear of censorship in his fictional diptych "Pożegnanie" ("Farewell") and "List" ("A Letter") (1948). A protagonist in the latter said to a friend returning to the country:

I don't want and I can't condemn myself to a lifetime of lying, which not only I couldn't talk about but which also you would make me justify .... I can't be quiet on behalf of any system and any political orientation when I know I should speak up ... Here thoughts dictate my words, there the permitted words would have started to dictate my thoughts ${ }^{5}$.

Nevertheless, his experience of going native in Guatemala reinforced his inherited sense of freedom as total self-responsibility. Without depriving himself of his national identity, of his Polish mother tongue and cultural engagement in European discourse, he learned to be a Guatemalan citizen just as he would have liked to be a Pole in Poland. He started his own business, he bought a house, he took root. On the one hand,

5 Bobkowski, A., “List”, in: A. Bobkowski, Coco de Oro, Lublin 1998, p. 65. 
he followed the middle-class paradigm of life, and on the other developed his modelmaking business, which was centred on creativity and inspired by dreams of flying and thus became an actually lived metaphor of freedom. In his letters to family and Polish friends, Bobkowski described Guatemala initially with enthusiasm as an already known country, as a familiar place and as close to his heart as Kraków or Zakopane in Poland. Guatemala provided him with the freedom to start a new life.

Bobkowski stated very clearly in his letter to Jerzy Giedroyć, the editor in chief of émigré Polish monthly "Culture" published in Paris, that one of the things he wanted to avoid after the war, was placing himself in a situation of a man dependent on the help of others, for some crumbs from the table or indeed a place at the table, repeating the helplessly self-comforting phrase "after all, they will not allow me to starve to death" (Giedroyć, 1997, 76). He classified such a perspective as the longstanding, humiliating effect of war and also the post-war order in Europe. He expressed this conviction in following words: "a European who does not want to be free, ceases to be a European. To stay one, I had to leave" (Bobkowski, 1998, 77). Bobkowski based his sense of independence on a number of simple conditions: he was proud to work and to earn money; he perceived his white-European origin as one of the accidents that befell a man and not a reason to humiliate others; he wanted to act rationally and remain independent also of local politics. Skin-colour or race were not so appealing questions to him as they were not a matter of choice. He wanted to be perceived as a free human being, not just as a white man. Above all the experience of WWII, the lessons of Nazism and communism made him aware how easy it was to label a group of people and promote hatred of them. Interestingly enough, for this very reason, he has never exposed his Guatemalan compatriots to his difficult WWII experiences. Querido Bob restrained himself from sharing traumatic memories and knowledge about the hostilities of WWII, from presenting himself as a courageous hero or a survivor, even from comparing the actual fear or danger at the time of he tGuatemalan revolt with those that filled his days in occupied France. It can be argued that in this way he protected his sense of integrity from a sense not only of victimhood but also from a sense of superiority deriving from his unique personal experience. He restrained from commenting, from issuing warnings, from giving lessons to Guatemalans because he did not feel in legitimate position to do so. Nevertheless, he observed on the Guatemalan streets unfriendly behaviours towards the white inhabitants which he felt subconsciously mirrored the racism which he had already experienced. To Bobkowski racism was a form of neglect of human beings in general and in its essence was like a disease that can affect all irrespective of race. Such remarkable distance from popular racist discourse appeared paradoxically as the solution to potential conflicts because it stopped a vicious circle of suspicion and started to build shared confidence between him and the local people, indigenous and non-indigenous alike. 
In the end an unavoidable consequence of his choices became isolation, since, as one may expect, his harsh criticism of Europe and distance from the local politics in Guatemala did not help him to find many friends and be warmly welcomed into different social circles. It would be an exaggeration to say that he was a loner, but the only society he enjoyed being identified with was "the Order of model makers", as he used to refer to the world of model makers. Symbolically, to join this order meant to leave the earth behind with its problems, become a citizen of the sky that served Bobkowski just as the sea served Conrad and music Chopin, and this realise the dream of a life without surveillance, of a life fulfilled by one's own choice.

Bobkowski chose the best metaphor for himself with surgical precision, expressing his sense of freedom, independence, and uniqueness all at once: "I am the emblem of Guatemala - their quetzal bird. There are only stuffed specimens, because alive in the cage, they will die after a few days. And I don't feel like dying and being gazed at stuffed" (Bobkowski, 2009a, 116). Curiously, the emblem of Poland is a crowned white eagle that signifies freedom and dignity. After WWII, the crown disappeared off the eagle's head because of the regime. Bobkowski identified himself with the quetzal bird, as the one who can live only by being free. His choice shows his choice to define freedom for himself and internalize its symbols. The narrow nationalistic approach to national symbols was left behind. It can be argued that Bobkowski translated the meaning of the freedom's national emblem.

\section{Guatemala in Bobkowski's writings}

Bobkowski felt at one with Guatemala, where he started a new life; he loved this country and therefore he felt entitled to comment on the political and social processes taking place at that time. Bobkowski, especially in the essays "Na tyłach" ["Behind the front"] (1949) and "Pytania dzikich ludzi" ["Savages' questions"] (1951), contrasted Europe with Guatemala or indeed all of Central America. Andrzej Bobkowski described his life in Guatemala, also providing a commentary about the world in the 1950s. This is particularly evident in "Notatnik modelarza" (2013) ["From a Diary of a Model Maker"], Coco de Oro (1970) and in his letters to his mother. However, his view of Guatemala changed from one of enthusiasm to a more lucid and critical observations, yet his attachment to this country remained unshaken. He was aware of the usual one-sided and depreciating perception of Guatemala, in the essay "Na tyłach" he wrote:

The World, the New World, the great Third World. We hardly talk about it, we mock the Guatemalas, Costa Ricas, San Salvadors and the Hondurases, amongst others, but what do we know about them? It is an incredibly rich area, wide and open, full of freedom and still yet has the best traditions of 
Europe. Who knows, maybe the spirit can survive right here, bloom and bear fruit again? I do not feel at all that I am in a small town, a small country. I feel above all a whole continent underfoot, vast, gorgeous and bursting with life (Bobkowski, 1998, 77).

Awareness of the socialist rule practised in central Europe prevented Bobkowski from feeling sympathy towards the socialist challenges for power in Guatemala and also reinforced his sympathy for the United States as the vanguard of capitalism and personal freedom. Bobkowski believed that president J. J. Arevalo was elected because he was a candidate proposed by leftist groups. Moreover, Arevalo proclaimed so-called spiritual socialism and welcomed many Spanish communists who came willingly and were rewarded with the best posts in the country, which was growing quickly in power (Bobkowski, 1970, passim).

In 1954, Bobkowski went to the United States to participate in the World Modelling Championships that was a highly important event for him for many reasons. First of all, the model business had begun to grow in popularity, so much so that a new competition emerged. Senior Andres realized that he had to expand his business again. "If I don't, others will do it for me. They will take the fruit from the tree, which I planted and nurtured patiently fought tooth and nail all this time since settling here" (Bobkowski, 1970, 203).

He realized that his participation in major competitions in New York could be an excellent advertisement for the new company he wanted to set up. The political situation in Guatemala and the overthrow of the communist president by the military junta complicated his plans. The writer managed to travel to a US military base on Long Island, a few days after the anti-communist guerrilla group led by Colonel Castillo Armas entered the capital city. Bobkowski demonstrated at these competitions a specially designed model that deviated from the generally accepted shapes. As he explained, the rubber-powered model gave the shape of a jet resembling the Russian MIG 15. His American friends joked "when you come with such a model and it's from Guatemala, they'll definitely summon you before the McCarthy commission" (Bobkowski, 1970, 209).

At the height of Guatemala's counter-revolution, aero modellers found themselves in the eye of a cyclone. Police officers suspected that the aero modellers intended to place a bomb in their radio-guided models and drop it onto President Jacobo Árbenz Guzmán. Although in the "Modeler's notes" the writer somewhat mockingly and dismissively described the emotions and horror experienced by his Guatemalan friend: when the police seized the models and destroyed their cameras, one needs to remember that this is a literary device, "and they say that these models are just toys" (Bobkowski, 1970,212). Making aero models seemed suspicious for the just about 
understandable reasons mentioned above, but equally a significant factor underlying the importance of this hobby is a freedom to spend time on activities not included in the current political agenda. How people spend their free time becomes a core theme of interest for any dictatorship, as it illuminates paths to freedom from it. Bobkowski knew that these were not just toys but materialized dreams. The writer repeatedly emphasized in his letters and articles the solidarity of modellers who created in Guatemala a kind of Christian order and mutual support. Even in the most intense period of counter-revolution, an aviation major armed to the teeth was building his dream plane in his spare time. "When that all this $s^{* * *}$ is over, I'll bring it to you. There's nothing like modellers. The model, the one in progress, is more important than everything" (Bobkowski, 1970, 224).

The American competition, which Bobkowski took part in with his younger fellow modellers Julio and Fernando Quevedo, was an opportunity to get to know people whom he had previously known only by correspondence. In New York, he met the modelling "guru" Frank Zaic who established one of the first companies producing supplies for model making. Two years later, Bobkowski went to Europe for the Swedish Championships to indulge his model-making passion. It was his only return to the Old Continent and his last meeting with family and friends.

Querido Bob was aware that the United States, like the Soviet Union, was trying to influence the hearts and minds of Latin Americans on various levels. The WWII period in Latin America was characterized by a class collaboration and, as noted by Castaneda, "an overwhelming dilution of political and ideological differences as well as the abandonment of any vestige of nationalism that implied criticism of, or antagonism against, the United States" (Castaneda, 1994, 30). The predominant goals of all progressive forces were an increase in production and a rise in the living standards of the working people. "During this period, Communist parties formed more broadly based fronts and national unions or found remarkably strange bedfellows among the local oligarchies" (Castaneda, 1994, 30). However, in 1947 the disintegration of USA-Soviet alliance affected Latin America's Communist parties, which were seriously weakened and divided. "The Communist parties' central, long-term objective remained a national-democratic revolution, agrarian reform, and an alliance with the middle classes and the national bourgeoisie, but the principal enemy was once again imperialism, reduced to the government of the USA" (Castaneda, 1994, 30). What is more, some of the most important populist parties fought against Communism and the USSR's influence in Latin America. Bobkowski perceived all these processes as alien to the local society that needed to shape its own national and political identity, to define its concept of society in relation to its own history and experience. He also addressed a need to redefine Guatemalan relations with Spain long before theoretical reflection on decolonization. 
As already mentioned, Bobkowski's insights into European politics, which were rooted in his own personal experience, in turn influenced how he viewed the political challenges in Guatemala, such as international cooperation, the role of the media and free market, and the spread of communism. Firstly, he questioned the politics of the Soviet Union and the notion of international cooperation as a means of improving local societies. He projected his suspicions, rooted in his very painful experience of the Polish and Soviet communist regimes, onto the Guatemalan revolution, which prevented him from becoming mesmerized by the promises and facile declarations of the leaders. He was sensitive to propagandistic language, rhetoric and the media power exploited in political games, which all use even objectively good things for their own goals as well as for the purpose of manipulation. It was in a different language, but the same message which Bobkowski listened to on Polish radio at night that he read in the comments on international politics in Guatemalan newspapers the following morning. Many times, he would confront a reader with details and facts presented uncritically in the media and even in scholarly literature and deconstructed such positive narration, as for example with Arbenz's the agrarian reform of Arbenz. Bobkowski acknowledged that the reform itself was indispensable, but he insightfully listed its weak points as follows:

It is well known that communist agricultural reforms never have economic but, above all, political objectives. And such a purely political objective can be seen in Arbenz's agriculture reform. These reforms faced the least line of resistance and covered only lands which were in the developed area of the country and were privately owned. There was no rush to divide the government's estates that provided a convenient excuse to create sovkhoz (Bobkowski, 2009, 113).

As one may notice when Bobkowski refers to the economy and management constantly, he highlights the importance of data, numbers, of legal and administrative decisions not only because of his academic background but also to show that everyone can learn how to interpret reality. It was not a mystery to him that the American Fruit Company expanded its business in Guatemala to increase both its own income and more importantly its influence. The tension between the USA and USSR brought Guatemala to the centre stage. Guatemala was geographically very close to the United States which was fighting against communism on different continents but at the same time ignored its encroachment not only in its own backyard but also far from USSR. Soviet influence in Guatemala gave rise to absurd imitations of Soviet culture such as the adaptation of the graphic design of the weekly periodical Octubre in 1949 to resemble Russian Cyrillic script. 
Secondly as already noted, as far as Bobkowski's upbringing was concerned, he was very much attached to the rules of the free market and rational economy. The importance of work in human life and a commitment the development of a culture of work, the reduction of unemployment, the growth of solidarity and mutual respect - all these issues elevated Bobkowski's reflections and remarks about Guatemala to a universal level. Bobkowski put creativity at the heart of the economy instead of income growth or an abstract idea of development and he insisted that an everyday effort to fulfil one's potential was of greatest value to society. He saw the value of work that brought people together and provided a realm for inspiring encounters, therefore he paved a third way, not communist, not liberal: a way of seeing work as a life experience, worthy in its own right, without any ulterior ideological goals. It is the human factor that adds value to work, not the other way round. In my view, such an attitude resonates with the motto on the Auschwitz gates "Arbeit macht frei" ("Work makes you free") and shows how deeply Bobkowski internalized and reworked the trauma of war. In his opinion, a man is free to work, not the other way round, and also a man is not free from work because work is a part of his essential creativity as a human.

The watchwords of post-WWII anti-communist liberalism were "intellectual freedom" and the "open society" (Isaac, 2002, 29). Bobkowski restrained himself from becoming a prophet of liberalism, but he also firmly stated his condemnation of censorship both in the People's Republic of Poland as well as in Guatemala. Bobkowski mocked so-called spiritual socialism as a paradigm of false values and expressed his irritation that some Guatemalans had been seduced by this ideology.

Thirdly, Bobkowski had the lucidity to detach the declared ideology from real life and was therefore able to point out different kinds of misunderstandings in the interpretation of ongoing political events in a very astute way. He observed the spread of communism in Europe and in Guatemala. The pattern was the same everywhere: a pledge of care and compassion, a pledge to introduce justice and equality, the claim of progress followed by the introduction of specialists: well-experienced communists brought in from other countries. All the key positions in the country were gradually taken over by the communists, though of course, the entire operation was conducted under a veil of democracy (Bobkowski, 2009b, 99110). In this system all schools were subordinated to the government and were transformed into political training institutions, all the organisations the government claimed to have created in order to support the economy and technical development were gradually and systematically destroyed, just as in Orwell's Animal Farm. At the beginning of 1953 the terror increased and Bobkowski admitted that the atmosphere reminded him of war: overwhelming fear, people denouncing each other, people disappearing, being imprisoned, tortured or killed on the streets. The 
Arbenzo government limited cultural exchange with non-communist countries, even Hollywood movies were banned and replaced by the Soviet ones. Bobkowski admitted that he thought of leaving the country. Limiting cultural interaction to the circle of communist countries was itself the sign of a totalitarian regime. The author of Point of Balance was well aware of how absurd works of art praising the working class and proclaiming the unity of workers all over the world were; he was equally aware of how illusive and dangerous their self-proclaimed dreams were. His economic education supported his critical view: where there is no profit then ideology must be the product. He knew that Guatemala needed to find its own form of governance because its social structure and history differed significantly from that history of tzarist and Soviet Russia as well as from that of capitalist America, where the American dream could only be realised only by a limited few. One takes a great risk when imposing a system of values and meanings taken from one context blindly to another. Bobkowski saw multiple deformations of the political ideas taken from Europe and these observations led him to a conclusion of universal import: "A mother country is a mother country, Poland is Poland, but what is more important is deeper - it is our uniquely human conscience which has no national allegiance" (Bobkowski, 1998, 249).

\section{Conclusion}

Bobkowski's redefinition of freedom is based on his individual experience as a Pole who survived WWII, an educated European disillusioned with the post-Yalta order, a writer, a model maker and finally as a cancer patient. There is no escape from freedom according to Bobkowski, who following Fromm's distinction, differentiates between two kinds of freedom: "freedom from" and "freedom to/of". Being free from something appears to be insufficient to achieve fulfilment, therefore a man has to be free to/for something. The point is to enjoy freedom actively: through work and creativity. Bobkowski understood the Guatemalan situation through the lens of Poland's experience without, however, drawing artificial parallels or making forced comparisons. The point of reference was his sensitivity and in-depth reflection on the strategies and mechanisms that shaped both society and individual citizens. The similarities, which he observed in the mechanisms whereby political ideas are introduced into different societies, influenced in turn his contemplation of the transcultural differences in the understanding and meaning of fundamental concepts such as socialism, race or freedom. As a Pole in Guatemala he declared his love and attachment to his new country and sharply criticized European journalists who wrote about Guatemala in a simplistic and facile way. 


\section{List of quoted literature and sources}

Applebaum, A., Iron Curtain: The Crushing of Eastern Europe 1944-1956, New York 2012.

Bobkowski, A., Coco de Oro, Lublin 1998.

Bobkowski, A., Tobie zapisuje Europę. Listy do Jarosława Iwaszkiewicza (ed. Zieliński, J.), Warszawa 2009a.

Bobkowski, A., Ikkos i Sotion oraz inne szkice, Warszawa $2009 \mathrm{~b}$.

Bobkowski, A., Pytania dzikich ludzi. "Kultura" 50, Paris 1951.

Buntownik. Cyklista. Kosmopolak. O Andrzeju Bobkowskim i jego twórczości (ed. Klejnocki, J.; St. Kowalczyk, A.), Warszawa 2011.

Castaneda, J., Utopia Unarmed. The Latin Left after the Cold War, New York 1994.

Davies, N., God's Playground: A History of Poland: 1795 to the Present, Oxford 2005.

Dybel, Pawel, The Roots of Polish National Identity, http://info-poland.icm.edu.pl/ classroom/roots.html [accessed 07.06.2021]

Franco, J., The Decline and Fall of the Lettered City. Latin America in the Cold War, Cambridge 2002.

Giedroyć, J., Bobkowski Andrzej. Listy 1946-1961 (ed. Zieliński, J.), Warszawa 1997.

Gosk, H., "Emocje Bobkowskiego", in: Buntownik. Cyklista. Kosmopolak. O Andrzeju Bobkowskim i jego twórczości (ed. Klejnocki, J., St. Kowalczyk, A.), Warszawa 2011, p. 98-107.

Kaliszewski, W., Andrzej Bobkowski 2003, 27.10.1913-26.06.1961, https://culture.pl/ en/artist/andrzej-bobkowski [02.08.2021]

Kemp-Welch, T., "Dethroning Stalin: Poland 1956 and its Legacy”, Europe-Asia Studies 58, p. 1261-84.

Kowalczyk, A. St., "Bobkowski, Gwatemala, ethos mieszczański”, in: Buntownik. Cyklista. Kosmopolak. O Andrzeju Bobkowskim i jego twórczości (ed. Klejnocki, J., St. Kowalczyk, A.), Warszawa 2011, p. 197-213.

Nowak, M., On an Electric Arc: Andrzej Bobkowski Writing (trans. Mikołaj Golubiewski), Berlin 2020.

Sambor, M., “Uwagi o prozie beletrystycznej”, in: Literatura polska na obczyźnie 19401960 (ed. Terlecki, T.), London 1964.

Terlecki, T., Spotkania ze swoimi, Wrocław 1999.

Wandycz, P., The Price of Freedom. A History of East Central Europe from the Middle Ages to the Present, London and New York 1992.

Zimand R., Wojna i spokój, [in:] Wojna i spokój. Szkice trzecie, Londyn 1984. 


\section{The meaning of freedom during the Cold War in the light of Andrzej Bobkowski's Guatemalan prose}

Keywords: freedom, Bobkowski, The Cold War, transcultural, Guatemala

The Polish writer Andrzej Bobkowski (1913-1961), who defined himself as "the hooligan of freedom", achieved posthumous fame and recognition from Polish readers, however, in Guatemala, his adopted home, he is known mainly as "Querido Bob" who founded the "Guatemala Hobby Shop". Bobkowski chose Guatemala as his home to defend his own sense of individualism and dignity which had been shaken by his disillusionment with Europe in the face of both Nazism and communism. From Bobkowski's perspective, his escape from Europe in general, and from the Polish Second Republic in particular was a way to remain free from the ossified pseudo-values of the old continent, which had failed the test of the Second World War. Bobkowski, especially in his essays "Na tyłach" ["Behind the front"] (1949) and "Pytania dzikich ludzi" [“Savages' questions"] (1951), contrasted Europe with Guatemala or indeed with all of Central America. Andrzej Bobkowski described his life in Guatemala, providing also a rich commentary about the world in the 1950s, particularly in "Notatnik modelarza" ["From a Diary of a Model Maker"] and in his letters to his mother. This paper aims to reconstruct and discuss how Querido Bob as a European understood the meaning of freedom and how he confronted his inherited paradigm of ideas with the reality of Guatemala and its society, which was facing its own challenges.

\section{Pomen svobode med hladno vojno $v$ luči proze Andrzeja Bobkowskega v zvezi z Gvatemalo}

Ključne besede: svoboda, Bobkowski, hladna vojna, transkulturnost

Poljski pisatelj Andrzej Bobkowski (1913-1961), ki se je sam označeval za »vandala svobode«, je postumno nesporno zaslovel in dosegel naklonjenost poljskih bralcev. V Gvatemali pa je znan predvsem kot tisti »Querido Bob«, ki je iznašel Guatemala Hobby Shop. Bobkowski si je Gvatemalo izbral za svoj dom, zato da je ubranil svoj čut za individualizem in dostojanstvo, ki ju je spodkopalo razočaranje nad odzivom Evrope na nacizem in komunizem. S pisateljeve perspektive je bil beg iz Evrope na splošno in posebej iz Druge poljske republike način, kako ohraniti svobodo pred okamnelimi psevdovrednotami stare celine, ki je padla na preizkusu druge svetovne 
vojne. Bobkowski je, predvsem v esejih »Na tyłach« (Za fronto, 1949) in »Pytania dzikich ludzi« (Vprašanja divjakov, 1951), Evropo primerjal z Gvatemalo ali celotno Srednjo Ameriko. Svoje življenje v Gvatemali in obširno razmišljanje o svetu v 50. letih pa je popisal predvsem v delu "Notatnik modelarza (Modelarjev dnevnik) in pismih materi. Članek raziskuje, kako je Querido Bob razumel pomen svobode in kako je konfrontiral podedovano paradigmo idej z gvatemalskim okoljem in družbo, ki se sooča $\mathrm{z}$ lastnimi izzivi.

\section{Sentido de libertad durante la Guerra Fría a la luz de la prosa de Andrzej Bobkowski en referencia a Guatemala}

Palabras clave: libertad, Bobkowski, Guerra Fría, transcultural

El escritor polaco, Andrzej Bobkowski (1913-1961), que se definía a sí mismo como «el vándalo de la libertad», póstumamente ganó una innegable fama y simpatía de los lectores polacos. Sin embargo, en Guatemala es conocido principalmente como aquel «Querido Bob» que inventó la Guatemala Hobby Shop. Bobkowski eligió Guatemala como su hogar para defender su propio sentido de individualismo y la dignidad socavado por la gravedad de la desilusión provocada por el fracaso europeo frente al nazismo y el comunismo. Desde la perspectiva de Bobkowski, la huida de Europa en general, y de la Segunda República polaca en particular, fue una forma de mantenerse libre de los pseudovalores petrificados del viejo continente, que había fracasado en la prueba de la Segunda Guerra Mundial. Bobkowski, especialmente en los ensayos «Detrás del frente» (1949) y «Pytania dzikich ludzi» (Preguntas de los salvajes) (1951), contrastó Europa con Guatemala o con toda Centroamérica. Andrzej Bobkowski describió su vida en Guatemala, proporcionando también una rica reflexión sobre el mundo en la década de 1950, particularmente en «Z dziennika modelarza» (Del diario de un modelista) y en las cartas a su madre. Este trabajo tiene como objetivo reconstruir y discutir cómo Querido Bob entendió el sentido de libertad y cómo enfrentó su paradigma heredado de ideas con el ámbito de Guatemala y su sociedad que experimenta sus propios desafíos. 


\section{O avtorici}

Anna Szczepan-Wojnarska je izredna profesorica za književnost na Univerzi kardinala Stefana Wyszyńskega v Varšavi. Med letoma 2012 in 2016 je vodila Inštitut za poljsko filologijo, od leta 2021 vodi Inštitut za literarne študije in od leta 2014 doktorski študij na Fakulteti za humanistične študije. Je avtorica dveh knjig: »... you will get married to a fire "J. Liebert. The experience of transcendence in the life and the works of Jerzy Liebert (2003) in To Forgive God. A figure of Job in the literature related to WWII (2008). Področja njenega raziskovanja so povezave med književnostjo in religijo, literarna antropologija in transkulturne literarne študije ter prevodoslovje.

Spletna stran: https://orcid.org/0000-0002-2981-2673

E-naslov: szczepanwojnarska@gmail.com

\section{About the author}

Anna Szczepan-Wojnarska is an associate professor in literature studies at the Cardinal Wyszynski University in Warsaw. She is head of the Institute of Polish Philology (2012-16), and of the Institute of Literature Studies since 2021 and since 2014 also the Chair of PhD Studies at the Faculty of Humanities. She has published the books "...you will get married to a fire" J. Liebert. The experience of transcendence in the life and the works of Jerzy Liebert (Krakow, 2003) and To Forgive God. The figure of Job in the literature related to WWII (Krakow, 2008). Her research interests include the relationship between literature and religion, literary anthropology and transcultural literary studies as well as translation theory, and she has also edited several volumes on these subjects.

ORCID: https://orcid.org/0000-0002-29th81-2673

E-mail: szczepanwojnarska@gmail.com 